Research Article

\title{
The Tale of a Disappearing Lagoon: A Habitat Mapping and Ecological Assessment of Fosu Lagoon, Ghana
}

\author{
Bernard Essel (D), Justice Kwame Gyesi (D), Richmond Kofi Addo, Wisdom Galley (D), \\ and Gideon MacCarthy
}

\author{
Ziongate Geospatial and Research Services, P.O. Box DL 869, Cape Coast, Ghana \\ Correspondence should be addressed to Bernard Essel; bernard@ziongategeospatial.com
}

Received 22 February 2019; Revised 20 August 2019; Accepted 11 September 2019; Published 4 November 2019

Academic Editor: Daniel I. Rubenstein

Copyright (c) 2019 Bernard Essel et al. This is an open access article distributed under the Creative Commons Attribution License, which permits unrestricted use, distribution, and reproduction in any medium, provided the original work is properly cited.

\begin{abstract}
Coastal regions of Ghana are primarily engaged in sea and lagoon fishing. Like many lagoons in Ghana, Fosu lagoon is a major source of livelihood for its surrounding communities. However, the lagoon and its associated marsh vegetation is under serious threat from human-induced interference. Due to this, the lagoon is considered as one of the most polluted lagoons in Ghana. Also, studies reveal that a major conservation challenge is the lack of inventory for the lagoon's associated vegetation. Hence, the research was to map and assess the lagoon's habitat and identify threats to the lagoon. In achieving the research objectives, remote sensing and GIS technique were used to effectively map the lagoon and the catchment area. The result indicated that the Fosu lagoon is characterized by a massive decline in lagoon size and the vegetation cover. Thus, the standing water has declined by 50.2 acres from 1970 to 2017 to physical development and weeds. Also, it was evident in the result that the lagoon's vegetation is now fragmented into six various vegetation types and the weeds in the lagoon make approximately one-third of the lagoon's vegetation cover. Also, adding to the threat of the lagoon were high levels of plastic waste and metal pollution. Hence, if current trend continues, the possibility of further degradation is very high. The main impact of this research was to provide evidence to the gradual disappearance of the Fosu lagoon.
\end{abstract}

\section{Introduction}

Coastal lagoons and its associated vegetation are important in the coastal ecosystems, and they provide important services as habitat for aquatic plants and animals, recreational, flood control, salt mining, and religious purposes [1, 2, 3]. According to [4], coastal zones are characterized by fragile, complex, and productive environments. Hence, they require a special attention from the public and the government institutions. However, a significant number of coastal lagoons globally have been lost through anthropogenic activities such as building in mangrove forest and contamination of lagoon through dumping of refuse and liquid waste. Additionally, natural occurrences such as the spread of invasive species and weeds and the global sea level rise have also impacted on altering the ecosystem of coastal lagoons [5]. Additionally, the associated vegetation for coastal lagoons continues to face a drastic decline, particularly the mangrove vegetation. In [6], it is discussed that $19 \%$ of the world's mangrove vegetation was lost between 1980 and 2005. As a result, this increases the vulnerability and risk faced by coastal communities. The depletion of mangroves in many developing countries is a cause for serious environmental and economic concerns [7].

Like many lagoons in Ghana, Fosu lagoon is a major source of livelihood for its surrounding communities [2, 8]. It serves as staging, feeding, and roosting areas for wading birds. However, the lagoon and its associated vegetation are under serious threat from human-induced interference [9]. Due to this, the lagoon is considered as one of the most polluted lagoons in Ghana. Also, a painstaking review of literature reveals that a major conservation challenge is the lack of inventory for the lagoon's associated vegetation. While few studies have been done on the status of the fishes in the Lagoon $[10,11]$, none has been tailored to identifying and taking inventory of the current extent and condition of the Fosu lagoon. Crucially, we cannot assess what we have 
not measured. Hence, the lack of ecological inventory of the lagoons' associated vegetation has made ecological assessment difficult. This has hindered time series analysis to know the rate of decline and further project accordingly. With the increasing destruction of the Fosu lagoon and its associated vegetation, it is increasingly becoming important to map and assess the lagoon's habitat and identify threats to the lagoon. In this background, the ultimate goal of this study is to map and assess the lagoon's habitat using GIS and remote sensing and identify threat to the destruction of the lagoon.

\section{Data and Methods}

2.1. Site Description. The Fosu lagoon is now one of the water bodies with dead zone. It lies between latitude $5^{\circ} 06^{\prime} \mathrm{N}-5^{\circ} 07^{\prime} \mathrm{N}$ and longitude $1^{\circ} 15^{\prime} \mathrm{W}-1^{\circ} 16^{\prime} \mathrm{W}$. The lagoon is located in Cape Coast in the southern part of Ghana and has a surface area of 97.3 acres. The average water depth of the lagoon is 1.6 metres. It is bounded by the sea to the south and surrounded by different vegetation cover. The Fosu lagoon (as shown in Figure 1) is made up of two standing water. Currently, the fish composition of the lagoon indicates that there are five species: Sarotherodon melanotheron, Heterobranchus bidorsalis, Pellonula leonensis, Liza falcipinnis, and Clarias gariepinus. The landcover in the Fosu lagoon catchment is dominated by introduced vegetation with little remnant areas of mangrove vegetation.

2.2. Research Approach. Remote sensing and GIS technique were used to develop a GIS database of the Fosu lagoon and its associated vegetation. In this research, a high-resolution aerial photo was acquired from the Town and Country Planning Department, Ghana, with a ground sampling distance (GSD or pixel size) of $0.39 \mathrm{~m}$. The reason for this choice of GSD was because of the small fragmented vegetation in the catchment of the lagoon, only a high GSD can effectively distinguish between the fragmented vegetation. The use of satellite imagery would appear to be a satisfactory option to survey and map the Fosu lagoon, but this method has not yet been proved capable of distinguishing the full range of the small fragmented vegetation of the Fosu lagoon. Satellite images, for instance, the LANDSAT image, with $30 \mathrm{~m}$ resolution capability and the SPOT image with $10 \mathrm{~m}$ resolution do not provide images of the quality needed to map small fragmented vegetation as small as $5 \mathrm{~m}$.

In mapping the Fosu lagoon and its associated vegetation, high-resolution aerial photo harmonizing with object-based classification technique was used. This method offers a promising and a better classification option than pixel-based classification, and in other to achieve the objective of extracting fragmented vegetation composition, water resources, and invasive species, the object-based classification offer such window of opportunity. Additionally, another key reason the traditional image classification technique (supervised and unsupervised) was not used is because you often get salt and pepper look in the classification output. Among many software that can perform object-based classification, the eCognition

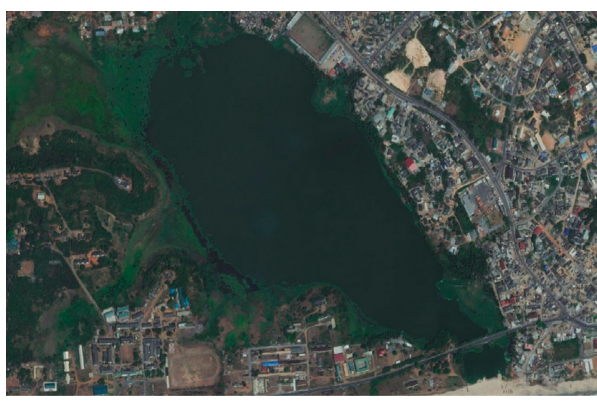

Figure 1: Aerial image of the Fosu lagoon.

software 9.3 was used because of its commercial maturity. The multiresolution segmentation was applied to group pixels into object and was subsequently classified using rule-based method (decision tree rule). The basic principles for the OBIA are as follows: (1) segmentation-break the image up into objects representing land-based features and (2) classification-classify those objects using their shape, size, and spatial and spectral properties. The high-resolution aerial photo was classified into seven classes, namely, standing water, mangrove vegetation, seminatural mangrove, coastal salt marsh, seminatural salt marsh, and introduced shrub and weeds. In defining the classes for the habitat of the Fosu lagoon, the handbook for phase 1 habitat survey prepared by Joint Nature Conservation Committee was used extensively.

2.3. Field Interviews and Visualization. Due to the difficulty in getting a reliable aerial photo from 1970s to 1990, an approach that can help translate qualitative data for visualizing was needed. This approach commonly known as sketch maps was adopted. Several studies such as [12, 13, 14] used such approach in translating qualitative data into maps. As a result, a structured historic data condition form was prepared for interviewing the old-indigene fishermen. Also, with the aid of a printed out aerial image, a total of ten (10) old-indigene fishermen were interviewed. Information concerning the initial extent and boundary of the lagoon and the associated vegetation, the previous water depth of the lagoon, and the previous condition of the lagoon was recorded. The information was then sorted and summarized (as shown in Table 1). Through the guidance of the historic data, a map was created to conform to the description in the historic data in ArcGIS software.

2.4. Accuracy Assessment. In other to ensure that the accuracy of the classification was acceptable, a field verification of the classification was done and after that accuracy assessment was done. In this approach, random GPS coordinates were picked on the field and its corresponding classification using RTK GNSS receiver. A total of $20 \mathrm{co}-$ ordinate points were picked. The coordinates points were retrieved from the RTK GNSS machine. The compute confusion matrix tool in the ArcGIS was used to calculate the overall accuracy and Kappa coefficient. 
TABle 1: Summary of Historic data from the field interview.

\begin{tabular}{lr}
\hline $\begin{array}{l}\text { Extent of the mangrove vegetation and standing } \\
\text { water }\end{array}$ & $\begin{array}{c}\text { Invasion of weeds } \\
\text { Ten respondents narrated that the standing water was } \\
\text { one big brackish water and was not divided into two } \\
\text { as it is now }\end{array}$ \\
$\begin{array}{l}\text { Six respondents shared a similar narration that the } \\
\text { mangrove vegetation around the lagoon was tick and } \\
\text { was about } 25 \text { to } 35 \mathrm{ft} \text { wide }\end{array}$ & $\begin{array}{r}\text { All ten respondents described that during the 1970s } \\
\text { to the 1990s, there was no presence of weeds in the } \\
\text { catchment of the lagoon }\end{array}$ \\
\hline $\begin{array}{l}\text { Seven respondents described that the mechanic } \\
\text { workshop land use was covered with shrub vegetation } \\
\text { during the } 1970 \mathrm{~s}\end{array}$ & $\begin{array}{r}\text { Six respondents reported that the standing water } \\
\text { stretched to about 20 ft at the upper part of the lagoon } \\
\text { (which is currently being occupied by weeds) }\end{array}$ \\
$\begin{array}{l}\text { Ten respondents narrated that shrub vegetation was } \\
\text { very dominant species aside the mangrove }\end{array}$ & \\
\hline
\end{tabular}

\section{Results}

Yevugah [15] considers kappa greater than 0.75 as excellent and between 0.4 and 0.75 to be fairly good. The recorded kappa coefficients obtained for 2009 and 2017 (as shown in Table 2) were therefore good enough for the analysis.

3.1. Spatial Extent of the Fosu Lagoon. The Fosu lagoon is characterized by a massive decline in lagoon size and the vegetation cover. It is evident in the result (Figures 2 and 3 ) that the lagoon's vegetation is now fragmented into various vegetation types over the past four decades. The maps (Figures 2, 3, and 4) shows the spatial extent of the lagoon and the catchment area in 1970, 2009, and 2017.

\subsection{Description of the Various Vegetation Classes}

3.2.1. Standing Water (Brackish Water). The standing water is brackish water which covered 147.5 acres in 1970, 112.4 acres in 2009 and 97.3 acres in 2017 (Table 3). Aside the area, the brackish water has consistently been reducing in depth as well.

3.2.2. Mangrove Vegetation. The mangrove vegetation class is made up of red mangrove (Rhizophora mangle). In the 1970s, the mangrove vegetation covered an area of approximately 53 acres; however, it has seen a decline from 10.54 acres in 2009 to 10.05 acres in 2017 . The red mangroves are native species of the lagoon's habitat. This is the only native species that still remain as a component of the lagoon's habitat. The original red mangrove over the past four decades has transformed or been converted into different landcover types. Although not completely lost, the red mangrove has reduced by $81.03 \%$.

3.2.3. Seminatural Mangrove. This vegetation class consists of red mangrove which is intermingled with crops. From the field survey, this vegetation class is intermingled with crops such as bananas and covers an area of 1.43 acres.

3.2.4. Coastal Salt Marsh. This coastal salt marsh class includes areas of herbaceous vegetation dominated by grasses.
TABle 2: Accuracy assessment of classified map in 2009 and 2017.

\begin{tabular}{ccc}
\hline Year & Overall accuracy (\%) & Kappa coefficient \\
\hline 2009 & 92 & 0.8599 \\
2017 & 90.0 & 0.8251 \\
\hline
\end{tabular}

It is a non-native species of the lagoon's habitat. It was created when the native red mangroves of the lagoon's habitat declined due to anthropogenic activities such as falling of the red mangroves and building of houses and commercial infrastructure. It covers an area of 9.14 acres.

3.2.5. Seminatural Salt Marsh. Unlike the coastal salt marsh class, the seminatural coastal salt marsh vegetation is intermingled with fruit plants and vegetable crops. It was evident from the field survey that there is a gradual change of the coastal salt marsh to farmlands.

3.2.6. Introduced Shrub. This class is one of the dominant vegetation in the lagoon's habitat. It is dominated by shrub species that are not locally native, whether planted or selfsown. It is made up of planted shrub species of Acacia. It is a non-native species which covers 59.83 acres of the vegetation cover of the lagoon's habitat.

3.2.7. Weeds. The lagoon vegetation cover is predominantly made up of weeds, thus covering 65.41 acres which constitute $38.7 \%(1 / 3)$ of the entire vegetation cover. It is by far the largest vegetation cover size. The weeds are found both within the lagoon and the fringes of the lagoon. It is a nonnative/invasive species which has grown steadily over the past four decades. The weed cover is polyspecific; two or more species coexist. It is considered one of the major threats to the decline of biodiversity in the lagoon's habitat.

\subsection{Identified Threats to the Lagoon}

3.3.1. Plastic Waste. The lagoon ecosystem finds itself under various threats spanning from varying anthropogenic activities. One major identified threat is the discharge of plastic waste into the lagoon. There are four main drains from the inner city of Cape Coast which connects to the lagoon. These 


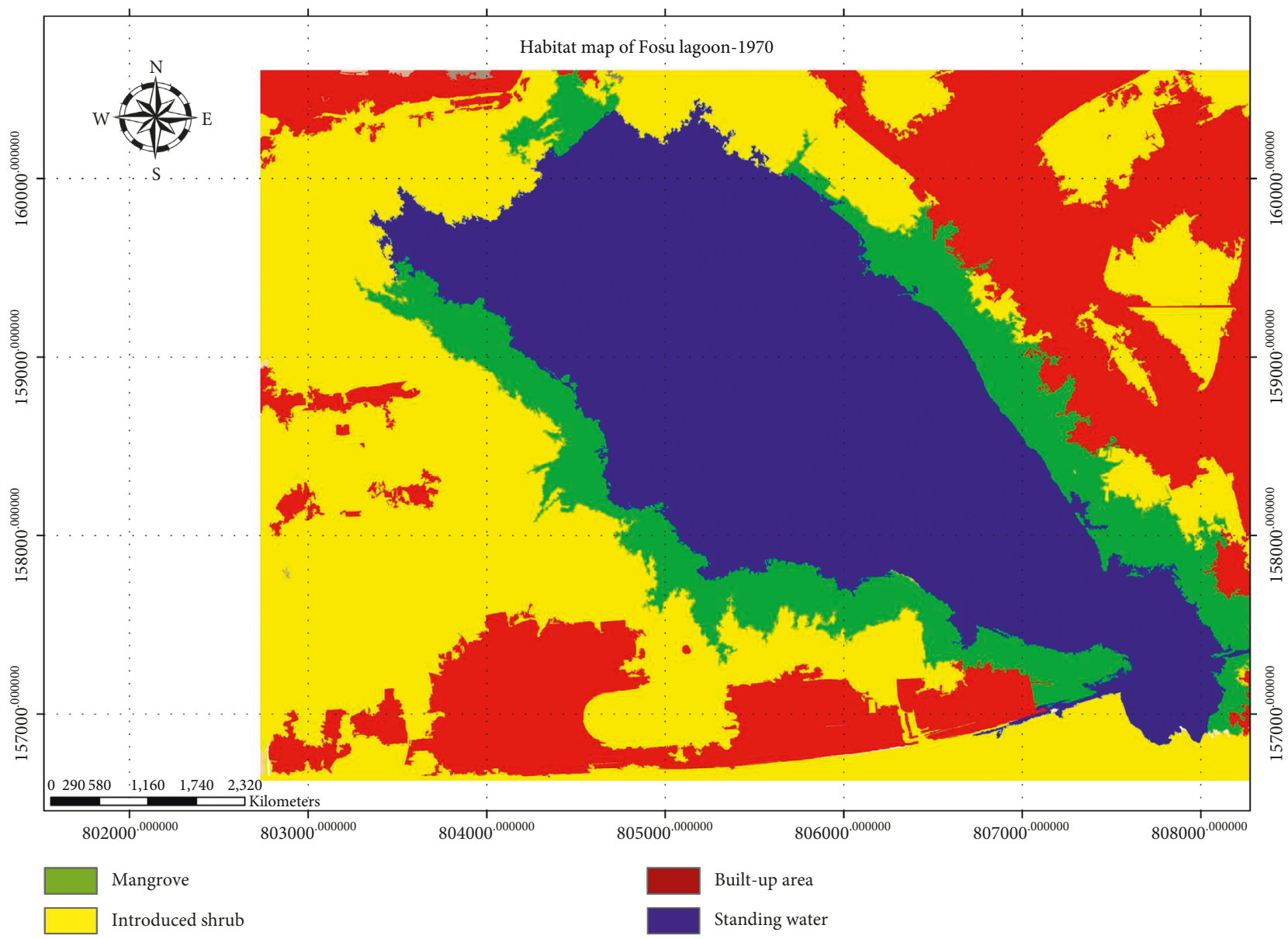

Figure 2: Habitat map of Fosu lagoon in 1970.

drains carry huge amounts of plastic waste which at the end finds itself floating in the lagoon. The overarching cause of this menace is from improper management of waste. The root cause of the improper management of waste is due to improper household waste disposal through indiscriminate dumping of waste in drains and unauthorized places.

3.3.2. Metal Pollution. One visible incompatible land use in the catchment of the lagoon is the mechanical workshop. It covers a vast area of 7.10 acres. This mechanical workshop is the biggest in the Metropolis and hence attracts and accommodates large number of vehicles. This mechanic workshop sits rightly at the edge of the lagoon.

\section{Discussion}

4.1. Fragmentation of the Lagoon's Habitat. A painstaking review of [16] discloses that the current state of the lagoon is as a result of anthropogenic activities: destruction of fringing mangroves, land use change, and discharge of domestic and industrial waste. However, from this study, one striking threat to the lagoon's habitat which was revealed is the fragmentation of the lagoon's vegetation. From the result, the lagoon is now fragmented in six vegetation classes, which originally was dominated by mangrove and shrub vegetation. The level of fragmentation of the lagoon's vegetation is high and poses a serious threat to the sustainability of the lagoon's habitat. According to [4, 17], habitat fragmentation is one of the primary causes of species extinction worldwide. In the case of the Fosu lagoon, the habitat fragmentation has caused reduction in the total area of continuous habitat, prevented wildlife from moving back and forth between patches of the vegetation, and has overall reduced the quality of the habitat. Also, the literature reveals that the fragmentation and modification of habitats have a negative effect of reducing the capacity of the habitat to provide a wide range of ecosystem services $[18,19]$. The Fosu lagoon's habitat is not an exemption since the modification of its habitat has reduced the range of ecosystem services it produces. Particularly, the provision services in the area of food have been affected. Armah et al. [16] posited that there has been a decline in the quantity of fishes in the lagoon. Also, cultural services in the area of beautiful landscape, cultural heritage, and healthy environment have all been negatively impacted. In addition, studies suggest that a mangrove belt of $100 \mathrm{~m}$ and $500 \mathrm{~m}$ wide can reduce a wave height of $13 \%-16 \%$ and $50 \%-100 \%$, respectively [20, 21]. However, with the fragmentation of the Fosu lagoon's vegetation into classes such as weeds, seminatural salt marsh, coastal salt marsh, and seminatural mangrove, the ability of these vegetation to reduce wave actions is possibly poor. 


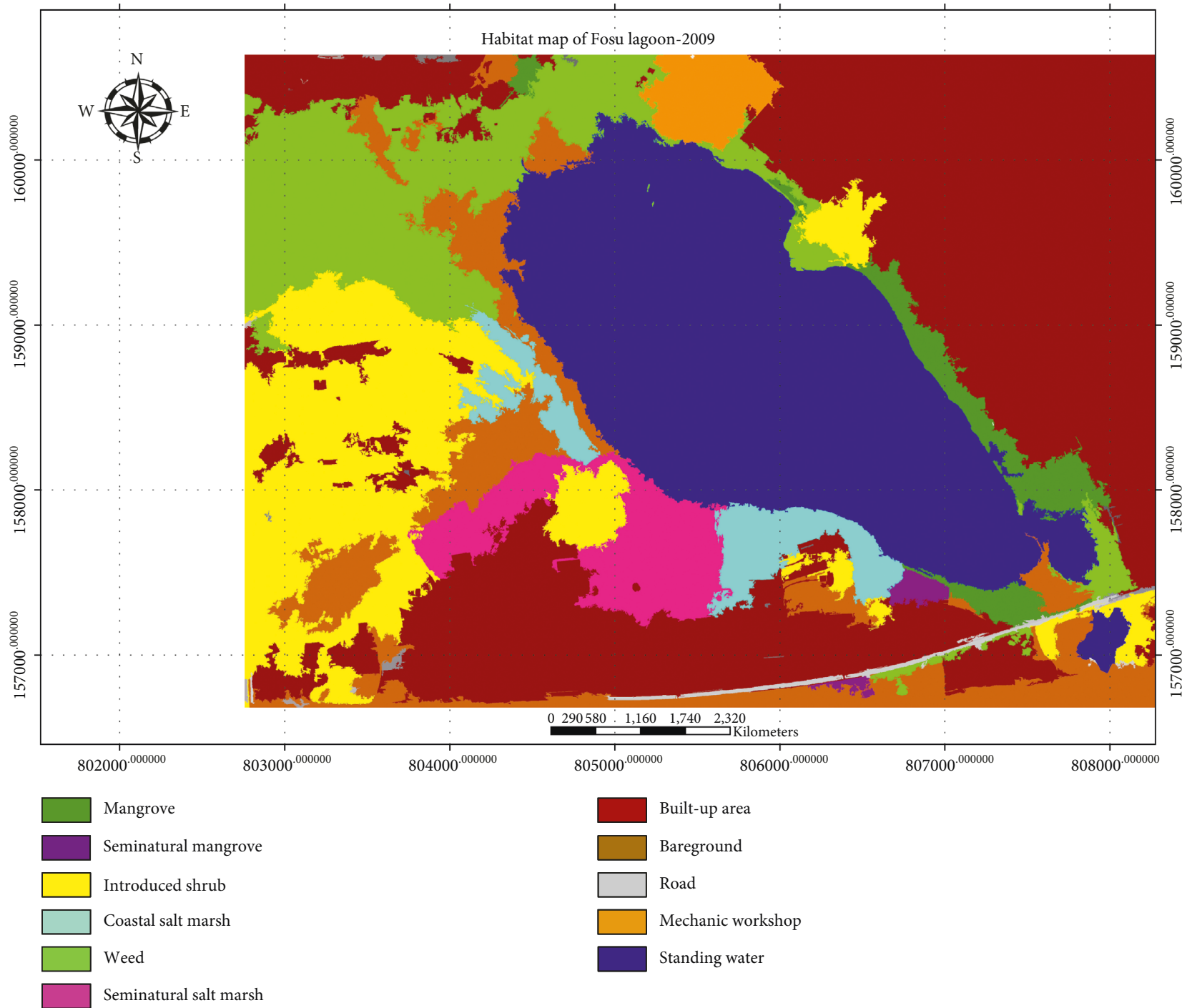

FIgURE 3: Habitat map of Fosu lagoon in 2009.

Thus, it will increase the vulnerability and risk faced by the adjoining coastal communities.

4.2. Land Use Change. Additionally, the land use and landcover change in the catchment of the lagoon have contributed to the poor state of the lagoon's habitat. In this study, the rapid urbanization of the Cape Coast Metropolis and weak land use regulation has contributed to the destruction of the lagoon's habitat. Particularly, the siting of important land use such as the hospital and stadium in the catchment of the Fosu lagoon's habitat has caused the area to develop rapidly and also raised the interest of land acquisition. High demand for land coupled with improvement in standard of living in the city has triggered urban dwellers to acquire environmental sensitive areas. Projection and scenarios through research indicate that urbanization will continue or accelerate in the future. This poses a lot of threat to the lagoon if nothing is done to curb the current situation.
4.3. Gradual Disappearance of the Lagoon. The massive loss of the mangrove vegetation in the catchment of the Fosu lagoon is a cause for serious environmental concern. From the result, the mangrove vegetation has declined by $81.03 \%$ and the possibility of continual reduction looms largely. Studies have revealed that, for example, Thailand has lost $84 \%$ of its mangroves [22], Jakarta Bay on the north coast of Java in Indonesia has experienced massive mangrove forest decline [23], and extensive mangrove degradation has cooccurred in KwaZulu-Natal, South Africa [24]. These evidences suggest that the mangrove forests in developing countries are under serious threat.

Also, the current state of the Fosu lagoon is no surprising since even worst situation has happened to Lake Chad. In the UN Environment report on the tale of disappearing lake [25], it was postulated that the size of Lake Chad has decreased by $90 \%$ due to overuse of water and extended drought and climate change. Although the drivers for the decrease in Lake Chad are different from those of Fosu lagoon, it is certain that the latter is also experiencing decline 


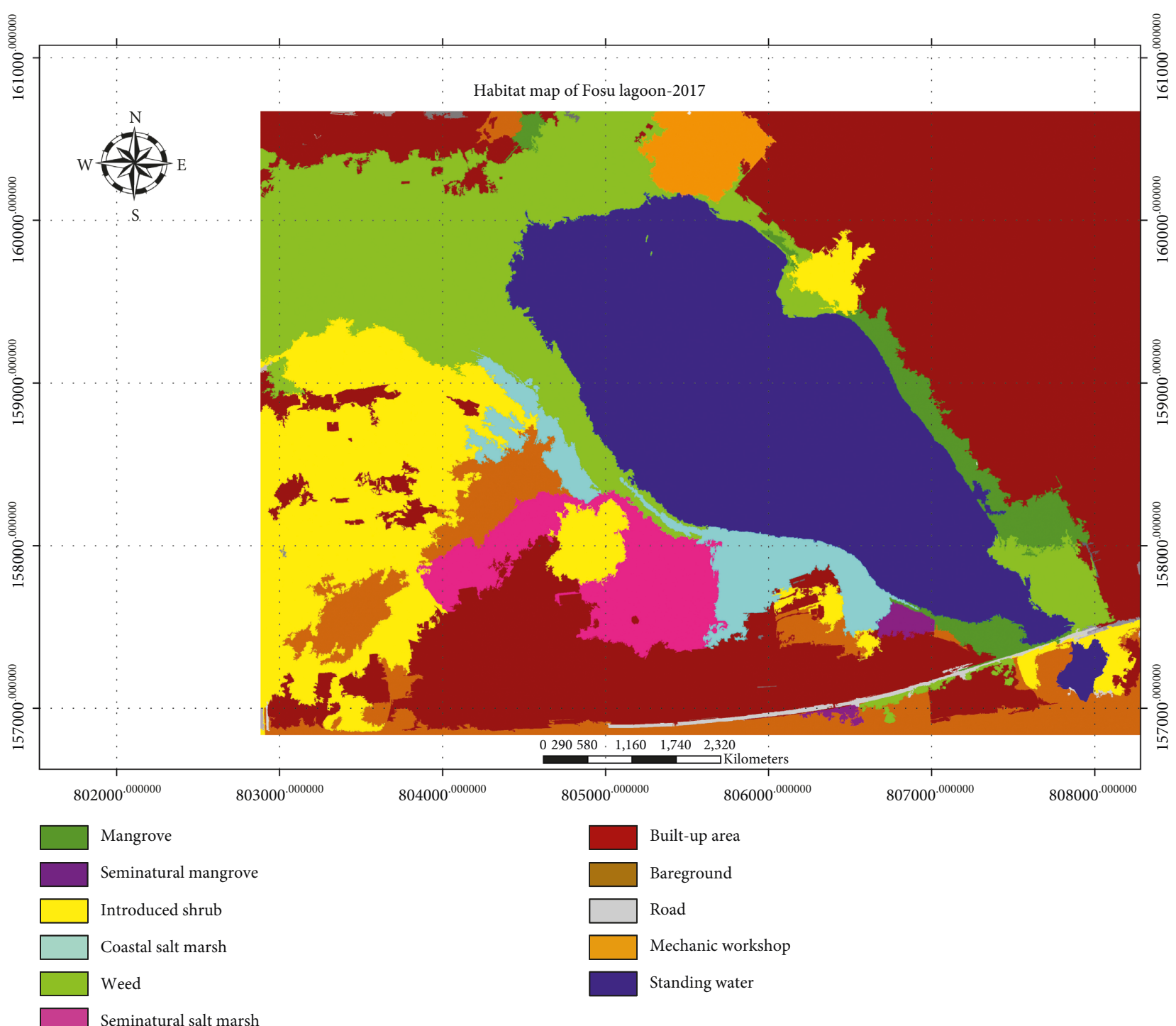

FIGURE 4: Habitat map of Fosu lagoon in 2017.

TABLE 3: Landcover size and percentage change of the various vegetation around the Fosu lagoon.

\begin{tabular}{lcccc}
\hline Landcover & \multicolumn{3}{c}{ Area (Acres) } & \multicolumn{2}{c}{$\begin{array}{c}\text { Change percentage } \\
\text { Increase (\%) }\end{array}$} \\
\hline Standing water & 1970 & 2009 & 2017 & Reduction (\%) \\
Mangrove vegetation & 147.55 & 112.94 & 97.33 & 81.03 \\
Seminatural salt marsh & 53 & 10.54 & 10.05 & 66.21 \\
Introduced shrub & - & 17.01 & 17.69 & 3.8 \\
Coastal salt marsh & 177.07 & 59.80 & 59.83 & 2.18 \\
Seminatural mangroves & - & 14.30 & 14.62 & 18.8 \\
Weed & - & 1.16 & 65.41 & 47.23 \\
Bare ground & - & 43.47 & 20.49 & - \\
Mechanic shop & - & 38.83 & 7.10 & - \\
Built-up & - & 7.10 & 151.24 & 53.54 \\
Total & 67.57 & 140.04 & 445.19 & 55.32 \\
\hline
\end{tabular}

and can get to the stage of Lake Chad. Currently, the standing water has reduced by $34.03 \%$. If the current trend continues, the possibility of further degradation is very high which might lead to the lagoon becoming a dead lagoon.
The habitat mapping and the ecological assessment of the Fosu lagoon done in this study have provided scientific evidence that the lagoon is disappearing. Many studies have used this approach to monitor the environment with a great 
success $[5,26,27,28]$. With the threats to lagoons and mangrove forest, the approach of mapping habitats and assessing them have proved to be more useful. Also, as posited by [29], the progression in GIS and remote sensing techniques promises in-depth and more accurate habitat mapping and assessment.

4.4. Plastic and Metal Pollution. Furthermore, the contributing driver for the high volume of plastic waste in the lagoon is as a result of these factors. Firstly, the metropolitan drain that enters the lagoon is wider in size $(5 \mathrm{~m})$; thus, it carries large volume of wastewater into the lagoon. Secondly, it was identified that the community that the metropolitan drain passes through predominantly practices open refuse disposal. Consequently, if not all, almost all their refuse are washed away by runoff water when it rains into the metropolitan drain. In effect, it finds its way in the lagoon. In [30], it was revealed that the massive amount of plastic waste in lagoons is very harmful to aquatic life. Plastic pollution is a problem that plagues most lagoons or water bodies in the world [31]. In [32], Adrian postulated that one million birds and a hundred-thousand marine mammals die every year due to marine plastic pollution. The issue of plastic waste in the Fosu lagoon is more serious than the city authorities have imagined. One critical issue is the degradation of plastic can take anywhere from 500 to 1000 years. Thus, more plastic will be accumulated in the lagoon bed.

Evidence from the literature indicates that heavy-metal concentrations in the standing water and the lagoon's sediments are significantly higher during the dry season [33]. Also, another observation made was that the standing water showed high levels of nutrients (i.e., $\mathrm{PO}_{4}^{-}$and $\mathrm{NO}_{3}^{-}$) in the wet season, whereas $\mathrm{pH}$ and conductivity were higher in the dry season. The high levels of nutrient have a positive impact in the growth of aquatic plants such as the mangroves; however, it can as well cause a rapid growth of algae. The growth of algae reduces the amount of dissolved oxygen in the lagoon [34]. This confirms the current expansion of algae in the lagoon. Again, the findings from [33] revealed that there were high levels of metals (iron, lead, zinc, and manganese) in the lagoon sediment and high level of metal concentrations (iron, manganese, zinc, and lead) in fish samples The high level of lead concentration is a concern since it has no nutritional value [30]. In a scenario where nothing is done and the concentration levels of the lead keeps rising, the possibility of lead poising could be a reality.

\section{Conclusion}

This project studied into the mapping of the lagoon's habitat and detailing the current condition of the ecological units achieved a satisfactory result. The study revealed that there has been a drastic decline in the size of the lagoon's habitat, fragmentation of the lagoon's ecosystem, and increase in the level of plastic waste pollution and land use/landcover change on the lagoon's habitat. In general, the lagoon is gradually disappearing. The biodiversity loss and changes in the ecosystem services in the Fosu lagoon are of regional concern and have adversely affected the well-being of the surrounding communities. One significant impact the further degradation will bring will be to increase poverty among fishers and fishmongers. It is recommended that future research focuses on suitable measures which can be adopted to restore and improve the lagoon.

\section{Data Availability}

The primary data used to support the findings of this study are available from the corresponding author upon request.

\section{Conflicts of Interest}

The authors declare that there are no conflicts of interest regarding the publication of this paper.

\section{Acknowledgments}

We acknowledge the Oguaa Traditional Council for the permission they granted us and Ziongate Geospatial and Research Services for their great contribution to the project. We also acknowledge the Rufford Foundation for funding the project activity with grant number 21775-1.

\section{References}

[1] G. N. Ajonina, T. Agardy, W. Lau, K. Agbogah, and B. Gormey, "Mangrove conditions as indicator for potential payment for ecosystem services in some estuaries of western region of Ghana, West Africa," in Estuaries of the World, vol. 1, pp. 151-166, Springer International Publishing, Salmon Tower Building, NY, USA, 2017.

[2] E. Baffour-Awuah, "Health implications of polluted tilapia consumption-the perception of Fosu lagoon fishermen in Cape Coast, Ghana," Environment and Health Science, vol. 4, no. 10, pp. 78-87, 2014.

[3] L. Zhang, M.-H. Wang, J. Hu, and Y.-S. Ho, "A review of published wetland research, 1991-2008: ecological engineering and ecosystem restoration," Ecological Engineering, vol. 36, no. 8, pp. 973-980, 2010.

[4] D. Mullu, "A review of the effects of habitat fragmentation on ecosystems," Journal of Natural Sciences Research, vol. 6, no. 15, pp. 1-15, 2016.

[5] M. S. Glimore, E. H. Wilson, and N. Barrett, "Integrating multi-temporal spectral structural information to map Wetland vegetation in a lower connecticut river tidal marsh," Remote Sensing of Environment, vol. 112, no. 11, pp. 1-13, 2008.

[6] Wealth Accounting and the Valuation of Ecosystem Services (WAVES), Valuing the Protection Services of Mangroves in the Philippines, Policy Briefing, Philippines, 2017, http://www. wavespartnership.org.

[7] R. Chevallier, "Balancing development and coastal conservation: mangroves in mozambique," Research Report 14 on Governance of African's Resources Programme, pp. 1-64, SAIIA, Johannesburg, South Africa, 2013.

[8] J. Blay Jr. and A. Asabere-Ameyaw, "Assessment of the fishery of a stunted population of the cichlid, Sarotherodon melanotheron (Rüppel), in a "closed" lagoon in Ghana," Journal of Applied Ichthyology, vol. 9, no. 1, pp. 1-11, 1993.

[9] D. K. Essumang, D. K. Dodoo, and S. B. Kendie, "The effects of leachates from solid waste disposal site on the Cape Coast 
municipality environment," Ghana Journal of Chemistry, vol. 7, no. 1, pp. 20-26, 2006.

[10] E. K. Abban, K. A. Asante, and T. M. Falk, "Environment of blackchin tilapia, Saratherodonmelanotheron, and their potential effects on the genetic structure of stocks in Ghana," in Proceedings of the ICIARM Conference, E. K. Abban, C. M. V. Casal, T. B. M. Falk, and R. S. V. B. Pullin, Eds., pp. 63-71pp. 63-Biochemistry and Sustainable Use of Fish in the Coastal Zone, Manila, Philippines, 2000.

[11] H. R. Dankwa, T. Quarcoopome, S. A. Owiredu, and E. Amedorme, "State of fish and fisheries of Fosu lagoon, Ghana," International Journal of Fisheries and Aquatic Studies, vol. 4, no. 2, pp. 259-264, 2016.

[12] E. E. Boschmann and E. Cubbon, "Sketch maps and qualitative GIS: using cartographies of individual spatial narratives in geographic research," The Professional Geographer, vol. 66, no. 2, pp. 236-248, 2013.

[13] L. Knigge and M. Cope, "Grounded visualization: integrating the analysis of qualitative and quantitative data through grounded theory and visualization," Environment and Planning $A$, vol. 38, no. 20, pp. 21-37, 2006.

[14] S. A. Matthews, J. E. Detwiler, and L. M. Burton, "Geoethnography: coupling geographic information analysis techniques with ethnographic methods in urban research," Cartographica: The International Journal for Geographic Information and Geovisualization, vol. 40, no. 4, pp. 75-90, 2005.

[15] L. L. Yevugah, "Spatial mapping of carbon stock in mangroves in the ellembelle district, Ghana," Thesis Submitted to Kwame Nkrumah University of Science and Technology, Master of Philosophy in Geomatic Engineering, Kumasi, Ghana, 2016.

[16] F. A. Armah, I. Luginaah, M. Kuitunen, and P. Mkandawire, "Ecological health status of the Fosu lagoon, southern Ghana II: environmental and human health risk assessment," Journal of Ecosystem and Ecography, vol. 2, no. 1, pp. 1-10, 2012.

[17] M. Parker and R. Mac Nally, "Habitat loss and the habitat fragmentation threshold: an experimental evaluation of impacts on richness and total abundances using grassland invertebrates," Biological Conservation, vol. 105, no. 2, pp. 217-229, 2002.

[18] D. Bailey, M. H. Schmidt-Entling, P. Eberhart et al., "Effects of habitat amount and isolation on biodiversity in fragmented traditional orchards," Journal of Applied Ecology, vol. 47, no. 5, pp. 1003-1013, 2010.

[19] Y. Haila, "A conceptual genealogy of fragmentation research: from island biogeography to landscape ecology," Ecological Applications, vol. 12, no. 2, pp. 321-334, 2002.

[20] Y. Mazda, M. Magi, Y. Ikeda, T. Kurokawa, and T. Asano, "Wave reduction in a mangrove forest dominated by Sonneratia Sp.", Wetlands Ecology and Management, vol. 14, no. 4, pp. 365-378, 2006.

[21] World Bank, "Managing coasts with natural solutions: guidelines for measuring and valuing the coastal protection services of mangroves and coral reefs," in Wealth Accounting and the Valuation of Ecosystem Services Partnership, M. W. Beck and G. M. Lange, Eds., pp. 1-25, WAVES and World Bank, Washington, DC, USA, 2016.

[22] C. Berlanga-Robles, A. Ruiz-Luna, and R. Hernandez-Guzman, "Impact of shrimp farming on mangrove forest and other coastal Wetlands: the case of Mexico," in Aquaculture and the Environment-A Shared Destiny, pp. 18-28, IntechOpen Limited, London, UK, 2011.
[23] Y. Nur, S. Fazi, N. Wirjoatmodjo, and Q. Han, "Towards wise coastal management practice in a tropical megacity-Jakarta," Ocean \& Coastal Management, vol. 44, no. 5-6, pp. 335-353, 2001.

[24] A. T. Forbe, N. T. Demetriades, and D. P. Cyrus, "Biological significance of harbours as coastal habitats in KwaZulu-Natal, South Africa," Aquatic Conservation: Marine and Freshwater Ecosystems, vol. 6, no. 4, pp. 331-341, 1996.

[25] UN Environment, "The tale of a disappearing lake," 2018, http://www.unenvironment.org/news-and-stories/story/taledisappearing-lake.

[26] M. S. Alam, J. A. Khan, B. J. Pathak, and S. Kumar, "Assessment of forest density using geospatial techniques of a tropical protected area," International Journal of Scientific and Research Publications, vol. 4, no. 3, pp. 1-6, 2014.

[27] K. C. Fickas, W. B. Cohen, and Z. Yang, "Landsat-based monitoring of annual wetland change in the Willamette valley of Oregon, USA from 1972 to 2012," Wetlands Ecology and Management, vol. 24, no. 1, pp. 73-92, 2012.

[28] N. Kumar, S. S. Yamac, and A. Velmurugan, "Applications of remote sensing and GIS in natural resource management," Andaman Science Association, vol. 20, no. 1, pp. 1-6, 2015.

[29] B. W. Heumann, "Satellite remote sensing of mangrove forests: recent advances and future opportunities," Progress in Physical Geography: Earth and Environment, vol. 35, no. 1, pp. $87-108,2011$.

[30] American Chemical Society, Better Managing Plastic Waste in a Handful of Rivers Could Stem Plastic in the Ocean, Science Daily, Rockville, MD, USA, 2017, http://www.sciencedaily. com/release/2017/10/1710110917754.htm7.

[31] C. Schmidt, T. Krauth, and S. Wagner, "Export of plastic debris by rivers into the sea," Environmental Science and Technology, vol. 51, no. 21, pp. 12246-12253, 2017.

[32] R. Adrian, "Saving the world: business ideas for cleaning ocean from plastic waste," 2014, http://www.cleverism.com/ saving-world-business-ideas-cleaning-ocean-plastic-wste/.

[33] F. B. Eshun, "Distribution of Heavy Metals in the Fosu Lagoon, Cape Coast, MSc thesis, Kwame Nkrumah University of Science and Technology, Kumasi, Ghana, 2011.

[34] N. M. Dubrovsky, K. R. Burow, G. M. Clark et al., "The quality of our nations water-nutrients in streams and ground water; 1992-2004," U.S. Geological Survey Circular, vol. 1350, pp. 174-185, 2010. 

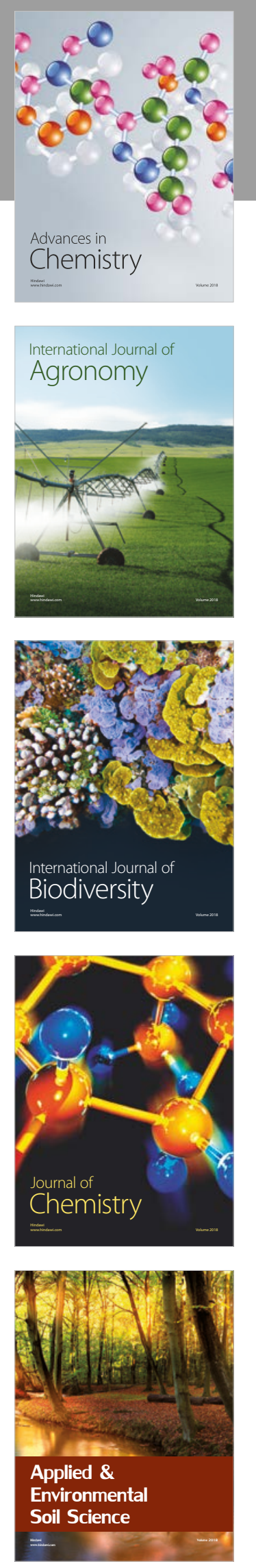

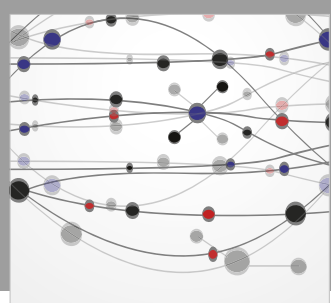

The Scientific World Journal

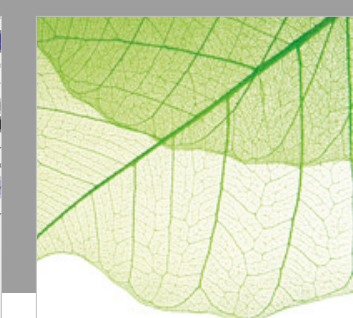

Journal of Botany

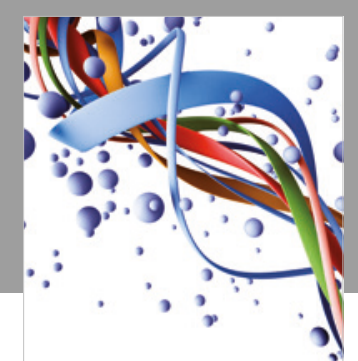

Scientifica

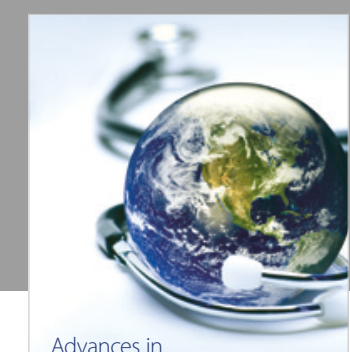

Public Health

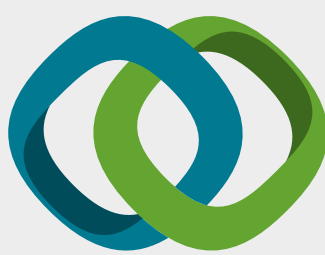

Hindawi

Submit your manuscripts at

www.hindawi.com
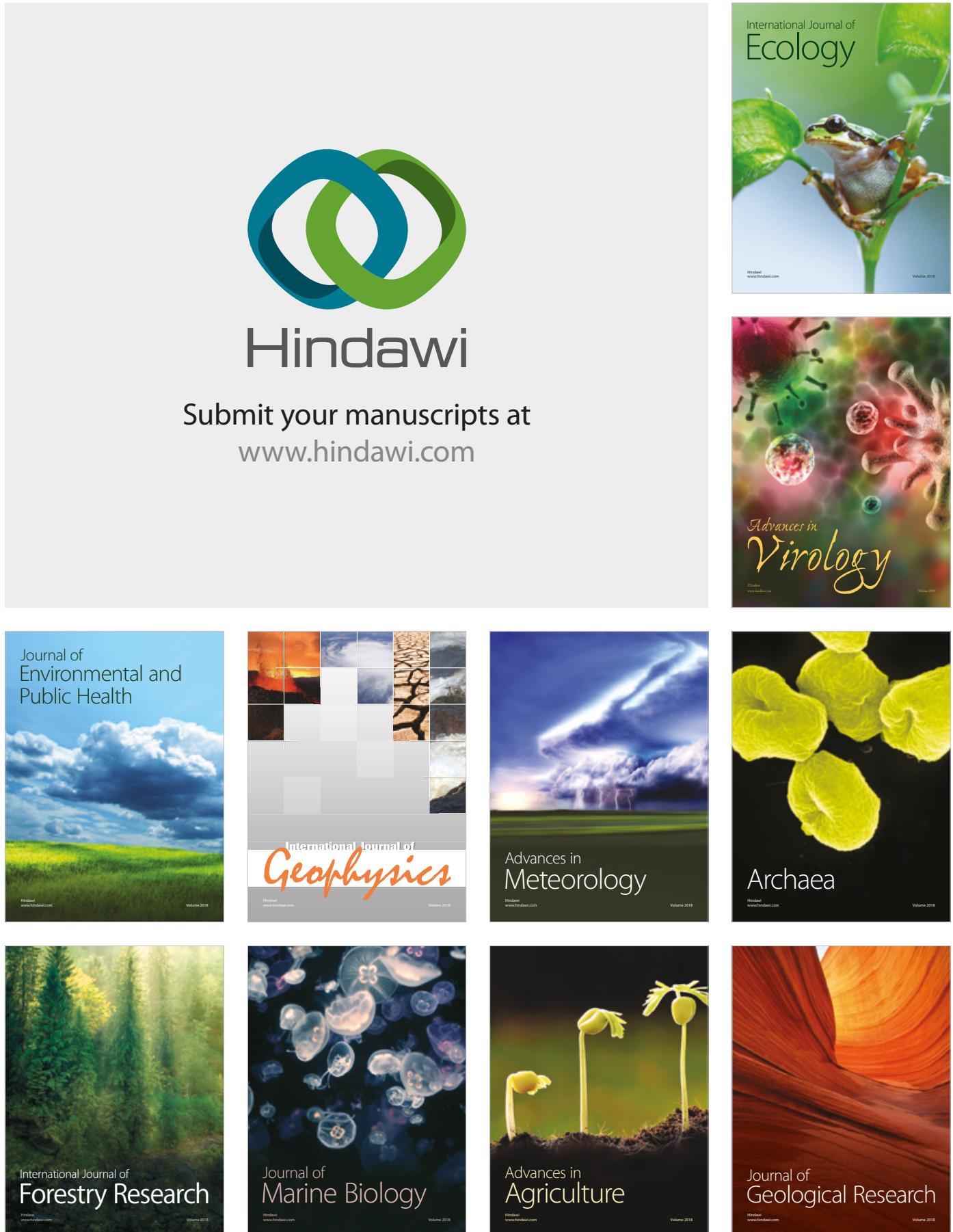

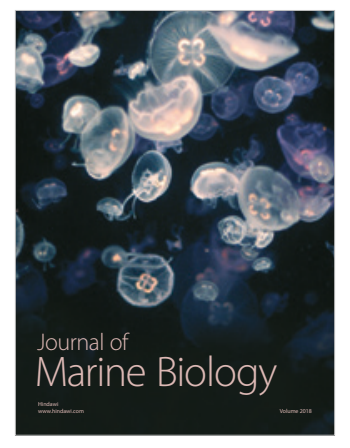

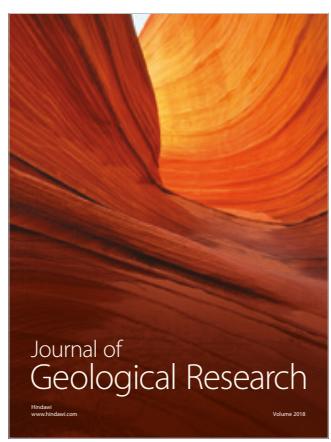

